\title{
CONHECIMENTO TRADICIONAL: TENSÕES E PERSPECTIVAS
}

Nilton Cesar da Silva Flores

0 primeiro autor é Advogado e Professor do Curso de Direito da Universidade Federal Fluminense, além de compor o Curso de Pós-Graduação em Direito da Universidade Estácio de Sá do Rio de Janeiro. Já a segunda autora, além de Advogada, é Doutoranda em Direito e orientada do primeiro autor na Universidade Estácio de Sá. É também Professora no Curso de Direito da FACHA/RJ e da IBMEC, bem como Professora Substituta no Curso de Direito da UFRJ.

VERONICA LAGASSI

Advogada e Doutoranda em Direito e orientada do primeiro autor na Universidade Estácio de Sá. É também Professora no Curso de Direito da FACHA/RJ e da IBMEC, bem como Professora Substituta no Curso de Direito da UFRJ.

\section{Resumo}

Diante da globalização tornou-se um grande desafio nacional a manutenção e proteçáo dos conhecimentos tradicionais e do patrimônio genético. Conhecimentos tradicionais são todos aqueles comuns e pertencentes a um povo, construídos a partir de práticas, costumes e crenças, que são transmitidos de geração em geração e cuja existência gera reflexos diretos na cultura de um país. Além disso, a sua concepção pode estar associada ao patrimônio genético do país. O que elevaria a relevância de sua proteção. Uma vez que, podem interferir não só na identidade cultural como também no desenvolvimento econômico do mesmo. Posto que, podem representar a riqueza tecnológica de uma naçáo ante sua utilização para fins da indústria farmacêutica, biomédica, do agronegócio, entre outros. Diante disso, a sua proteção deveria ser objeto de exaltação legal, principalmente no caso dos países em desenvolvimento. No entanto, não é bem isso o que acontece. Pata tanto, basta verificar a tímida legislação brasileira sobre a matéria. Fato que torna a sua proteção ineficaz. Posto que carente de definiçóes e conceitos essenciais e necessários para um controle adequado de sua exploração.

É com base nisso, o surgimento da defesa de que a melhor forma encontrada para sua proteção seria por intermédio da utilização das indicações geográficas. Instituto da Propriedade Industrial, que por ter reconhecimento internacional, iria garantir a adequada proteção ao conhecimento tradicional brasileiro. 


\section{Palavras-chave}

Conhecimentos tradicionais; Proteção e indicaçóes geográficas.

\section{Resumen}

Por fuerza de la globalización se ha convertido en un importante desafío nacional el mantenimiento y la protección de los conocimientos tradicionales y los recursos genéticos. Los conocimientos tradicionales son todos aquellos común y de pertenencia a una nación, construido a partir de las prácticas, costumbres y creencias, que se transmiten de generación en generación y cuya existencia genera un impacto directo en la cultura de un país. Además, su concepción puede estar asociada con el patrimonio genético del país. Lo que eleva la importancia de su protección. Puesto que pueden interferir no sólo en la identidad cultural, así como el desarrollo económico de la misma. Dado que, puede representar la riqueza tecnológica de una nación en contra de su uso para fines de la industria farmacéutica, biomédica, la agroindustria, entre otros. Por lo tanto, su protección debe ser objeto de una exaltación legal, especialmente en el caso de los países en desarrollo. Sin embargo, no es exactamente lo que sucede. Por lo tanto, basta simplemente analisar la legislación brasileña al respecto. Hecho que hace que su protección sea ineficaz. Aunque carece de definiciones y conceptos esenciales y necesarios para el control adecuado de su explotación.

Es sobre esta base, la aparición de la defensa que la mejor manera encontrada por su protección, que és por medio de la utilización de las indicaciones geográficas. Instituto de la Propiedad Industrial, que tiene reconocimiento internacional, se garantizaría una protección adecuada a los conocimientos tradicionales del Brasil.

\section{Palabras clave}

Conocimientos tradicionales; Protección y indicaciones geográficas.

\section{Introdução}

Os Conhecimentos Tradicionais seriam todos aqueles que são fruto da experiência humana em uma dada região, sendo transmitidos verbalmente, de geração a geração, interferindo diretamente nos costumes e crenças de um povo. Esses conhecimentos podem ser materiais ou não, mas estão sempre vinculados a cultura ou aos costumes de um determinado lugar. E, por serem fruto do experimento humano, diferem-se do conhecimento científico, pelo fato deste último ter sido objeto de pesquisa e da adoção de um método para sua obtenção.

Assim, o conhecimento tradicional não goza de observância ou respeito a qualquer critério cientifico apesar de normalmente fazer uso do procedimento empírico (experimentação). 
Porém, ainda que o conhecimento tradicional não possa ser classificado como objeto do intelecto, a sua importância impede que ele seja dissociado do âmbito de sua proteção como instituto "sui generis" da propriedade intelectual. Isso porque os conhecimentos tradicionais possuem uma natureza jurídica híbrida, tendo em vista que são ao mesmo tempo direitos de propriedade intelectual e indubitavelmente direitos humanos culturais. Neste último caso, pelo fato de poder representar a identidade cultural de um povo. Diante disso, é essencial pensar-se formas para sua proteção e foi isso que a Lei no 13123/2015 tentou fazer, porém sem muito êxito.

E, é justamente sob a ótica de sua proteção que apresentaremos as falhas da lei supracitada, bem como ao final sugerimos como meio para sua proteção a utilização da indicação geográfica.

Este é o cerne do presente trabalho, que traz como metodologia a pesquisa feita em fontes legais, jurisprudenciais e bibliográficas.

\section{Os Conhecimentos Tradicionais e suas Tensões}

Os Conhecimentos Tradicionais seriam todos aqueles que são fruto da experiência humana em uma dada região, sendo transmitidos verbalmente, de geração em geração, interferindo diretamente nos costumes e crenças de um povo. Podem ser materiais ou espirituais. E por serem fruto do experimento humano diferem-se do conhecimento cientifico, pelo fato deste último ter sido objeto de pesquisa e da adoção de um método para sua obtenção.

Assim, o conhecimento tradicional não goza de observância ou respeito a qualquer critério cientifico apesar de normalmente fazer uso do procedimento empírico (experimentação). Mas, ainda que não possa ser classificado como objeto do intelecto, a sua importância impede que ele seja dissociado do âmbito de proteção como instituto "sui generis" da propriedade intelectual.

Foi justamente por esta razão, que a sua relevância terminou por ser até bem pouco tempo ignorada. Especialmente, quando estamos nos referindo ao conhecimento tradicional pertencente aos países subdesenvolvidos ou em vias de desenvolvimento. Pois, neles, os conhecimentos tradicionais normalmente são ignorados até o momento em que seus povos perdem sua posse e domínio. E isso, simplesmente acontece porque para seu detentor o conhecimento tradicional é algo tão trivial e indissociável de sua cultura, que o torna presa fácil a terceiro mal intencionado na sua exploração.

Pois, conforme bem observam Simone Nunes Ferreira e Adriana Nogueira Rocha Clementino:

Nos últimos anos, o reconhecimento da importância desses conhecimentos e a discussão sobre formas de proteção aplicáveis têm permeado 
diferentes foros internacionais, tais como a Organização Mundial de Propriedade Intelectual, o Alto Comissariado das Naçôes Unidas para os Direitos Humanos e a Convenção sobre Diversidade Biológica. Esses foros demonstram que o tema pode ser examinado em diferentes dimensóes: a dimensão do direito privado reconhecido pelo Estado (propriedade intelectual), a dimensão do direito público protegido pelo Estado (direitos humanos) e a dimensão ambiental (acesso a conhecimento tradicional associado a recursos genéticos) ${ }^{1}$

Essa situação de ignorância a respeito dos conhecimentos tradicionais é bastante factível e pode ser ainda mais gravosa, quando esse conhecimento está atrelado ao patrimônio genético do país que originariamente o possuiu. Posto que, não são incomuns os casos em que o objeto de concessáo de patente foi fruto do aprimoramento ou transformação do conhecimento tradicional em conhecimento cientifico, realizado por terceiro. Este último, normalmente, um país desenvolvido.

E muito embora, pudéssemos sustentar a invalidade da supracitada concessáo com base na ausência da "novidade", pelo fato de se tratar de requisito indispensável para a concessão de uma patente. $\mathrm{O}$ fato é que isso dificilmente ocorre. Inicialmente, porque o país lesado é quase sempre aquele que está em vias de desenvolvimento. Aonde este tipo de conhecimento não é normalmente valorizado e não há meios legais estabelecidos para a sua proteção.

De modo que, essa ausência de valorização terá por sucedâneo a escassez de uma legislação efetiva para a proteção e controle da exploração dos conhecimentos tradicionais. Inclusive, podemos incluir o Brasil nessa situação.

Os conhecimentos tradicionais podem contribuir em muito dos casos para individualizar e até mesmo formar uma determinada identidade cultural regional.

Neste sentido, há quem defenda uma tênue distinçáo entre os conhecimentos tradicionais e os indígenas, cujo marco divisório seria a identidade de seus proprietários. Aonde, os primeiros teriam um acervo não escrito e respeitável no tempo de costumes, crenças, rituais e práticas legadas por seus ancestrais. Ao passo que, no caso dos proprietários dos conhecimentos indígenas não existe necessariamente uma reivindicação de ocupação territorial anterior ao seu habitat atual. O que conforme explicam Pierina German Castelli e John Wilkinson²:

1 FERREIRA, SIMONE NUNES. CLEMENTINO, ADRIANA NOGUEIRA ROCHA. Artigo: Proteção dos Direitos Tradicionais Associados à Biodiversidade. Revista Jurídica. Disponível em: http:// www.planalto.gov.br/ccivil_03/revista/rev_81/artigos/Simone_rev81.htm, retirado no dia 24.04.2015.

2 CASTELLI, Pierina German. WILKINSON, John. Conhecimento Tradicional, inovaçáo e direitos de proteçáo. (UFRRJ). P. 94. Disponível em: http://r1.ufrrj.br/esa/V2/ojs/index.php/esa/article/ view/221, retirado em: 09.04.2015. 
...o conhecimento indígena é um subconjunto do conhecimento tradicional, com a única diferença de que os possuidores são populaçôes indígenas em lugar de comunidades "não-indígenas" que incorporam estilos de vida tradicionais. Assim, a distinção não implica que o conhecimento indígena e o conhecimento tradicional são diferentes em si, mas aponta para o fato de que os proprietários do conhecimento indígena têm reivindicaçóes políticas mais amplas que os proprietários dos conhecimentos tradicionais.

No entanto, esta subdivisão nos é irrelevante para compreensão e estudo dos conhecimentos tradicionais como gênero do qual o conhecimento indígena seria espécie. Até porque, no caso do Brasil, país de grande miscigenação e de inegável composição cultural indígena, esta subdivisão torna-se irrelevante. $\mathrm{O}$ que faz com que a maior parte do conhecimento tradicional vinculado ao índio constitua patrimônio cultural do povo brasileiro. Náo custa nada lembrar, que o índio foi o primeiro habitante de nosso país. E, além disso, trata-se de um dos maiores detentores de conhecimento tradicional, ante seu contato direto com a natureza. É ele quem, normalmente, domina o conhecimento tanto na fauna quanto na flora de práticas medicinais e de cujo uso teria por fim o de curar doenças conhecidas por sua tribo.

Ademais, independentemente de sua subdivisão os conhecimentos tradicionais terão por características: a de enriquecerem-se a cada geração; serem adquiridos e comprovados empiricamente; relacionam-se ao território, ao uso de seus recursos naturais, inclusive genético e ao meio ambiente; podem ser expressos em uma dada comunidade na forma pela qual manejam a terra ou a agricultura, se organizam socialmente, praticam a espiritualidade, a medicina tradicional e as relaçóes entre animal e vegetal.

Tais características farão com que eles reflitam-se na cultura, religião, educação, saúde e o estado do meio ambiente. Daí a sua importância, tendo em vista que em última análise podem servir como forma de identificação de um povo.

Neste sentido, Stuart $\mathrm{Hall}^{3}$ vai defender que:

As culturas nacionais são uma forma distintivamente moderna. A lealdade e a identificação que, numa era pré-moderna ou em sociedades mais tradicionais, eram dadas à tribo, ao povo, à religião e à região, foram transferidas, gradualmente, nas sociedades ocidentais, à cultura nacional.

Assim, sob a ótica do que Hall defende os conhecimentos tradicionais seráo imprescindíveis à formação e manutenção da identidade cultural na pós-modernidade.

3 HALL, Stuart. (tradução de Tomaz Tadeu da Silva e Guacira Lopes Louro). A Identidade Cultural na Pós-modernidade. $11^{\mathrm{a}}$ ediçấo. Rio de Janeiro: DP\&A Editora, 2011. P. 49. 
Além disso, será a existência das características acima elencadas para os conhecimentos tradicionais que irá legitimar a doutrina a estabelecer um elo entre a proteção dos conhecimentos tradicionais e o reconhecimento às comunidades mais diversas sobre "seu conhecimento tradicional". O que propiciaria o poder de inibição ou controle sobre seu uso ou divulgação, bem como iria garantir benefícios para seguir investigando e possibilitaria o fortalecimento e crescimento econômico de seu detentor como comunidade.

Todavia, conforme observam Pierina German Castelli e John Wilkinson ${ }^{4}$ :

Os avanços da biotecnologia transformam a biodiversidade mundial num vasto gene pool, cujos recursos genéticos se tornam insumos estratégicos para o desenvolvimento de novos produtos e processos e permeiam grandes setores industriais (energia, fármacos, alimentos, cosméticos). Esta riqueza potencial se localiza, sobretudo, nos países em desenvolvimento, cujos centros de diversidade biológica ainda resistem aos avanços da Revolução Verde. $\mathrm{O}$ acesso a esses recursos, fonte de grande tensão entre países e diferentes atores sociais, coloca as grandes empresas e negociadores dos organismos internacionais diretamente em contato com comunidades tradicionais e indígenas, provocando uma discussão sobre direitos que dificilmente se enquadra nas legislações vigentes.

Isso porque, os conhecimentos tradicionais correspondem à bem intangível, advindo da experimentação praticada por povo de uma determinada região. Eles estáo diretamente correlacionados ao Direito de Propriedade Intelectual. Porém, com esta última inicialmente não se coadunam. Justamente, pelo fato de não serem fruto da tecnologia e sim, da experiência transmitida de geração em geração. O que torna sua natureza jurídica sui generis, tendo em vista não serem concebidos pelo intelecto ao contrário do que ocorre com o conhecimento cientifico.

Contudo, esta natureza jurídica sui generis em nada irá diminuir a sua importância e consequentemente, a necessidade de sua proteção. Nesse sentido, Stephen B. Brush ${ }^{5}$ vai defender a essencialidade da biodiversidade, dos recursos genéticos e do conhecimento tradicional no bem-estar de uma população e suas geraçôes, tornando-se importante esse conhecimento, tanto para os esforços dirigidos à sua conservação quanto para identificar componentes ou genes úteis.

4 CASTELLI, Pierina German. WILKINSON, John. Conhecimento Tradicional, inovação e direitos de proteçáo. (UFRRJ). P. 89. Disponível em: http://r1.ufrrj.br/esa/V2/ojs/index.php/esa/article/ view/221, retirado em: 09.04.2015.

5 BRUSH, Stephen B. Whose Knowledge, Whose Genes, Whose Rights? In: Valuing Local Knowledge: Indigenous People and Intellectual Property Rights. Edited by Stephen B. Brush e Doreen Stabinsky, 1996; 
E é justamente com base em sua importância e na proteção de uma dada identidade regional, que o conhecimento tradicional foi objeto de preocupação da Organização Mundial da Propriedade Intelectual, conforme destacam Ferreira e Clementino:

A Organização Mundial da Propriedade Intelectual - OMPI estabeleceu o Comitê Intergovernamental sobre Propriedade Intelectual e Recursos Genéticos, Conhecimentos Tradicionais e Folclore (IGC - sigla em inglês), por intermédio de sua Assembléia Geral, realizada em outubro de 2000, como um fórum internacional para o debate e diálogo sobre as interfaces entre propriedade intelectual, conhecimento tradicional, recursos genéticos e expressóes culturais tradicionais (folclore)(2). O IGC tem procurado determinar os elementos relativos a um sistema sui generis de proteção dos Conhecimentos Tradicionais Associados desde $2001^{6}$.

Com objetivo semelhante o conhecimento tradicional estará previsto na Lei Brasileira através do artigo 45, inciso II, 2a parte, da Lei no 9610/98 (Lei do Direito Autoral) como bem pertencente ao domínio público. Ou seja, trata-se de bem de propriedade da população brasileira posto que contribui à manutenção de sua identidade cultural.

Essa propriedade garante-nos o direito de usar, gozar e dispor deste bem, que é o conhecimento. Além de reavê-lo de quem quer que o possua ou o detenha injustamente.

Insta observar, que o direito de propriedade está regulado e protegido por leis infraconstitucionais. Muito embora, a Constituição Federal Brasileira de 1988 também o mencione em seu art. 5o, inciso XXII. Além disso, por tratar-se de bem cuja natureza jurídica está atrelada ao Direito à Propriedade Intelectual, teremos também a observância de Acordos e Tratados Internacionais que o mencionem.

Neste aspecto, a Comissão sobre Propriedade Intelectual e Industrial defende ser benéfica a atribuição da propriedade dos conhecimentos tradicionais a um país. Uma vez que, ela irá acarretar na redução de uma injustiça que se percebe mundialmente com a globalização disseminando tais conhecimentos. Além disso, também trará maior reconhecimento do valor econômico tradicional e respeito por quem o há reservado. Bem como, a melhora na qualidade de vida e grau de desenvolvimento.

Em consonância com o acima dito, também está a Convenção da Biodiversidade da Organização das Naçôes Unidas da qual o Brasil é signatário e que foi internalizada no ordenamento pátrio através do Decreto no 2519/98.

6 FERREIRA, SIMONE NUNES. CLEMENTINO, ADRIANA NOGUEIRA ROCHA. Artigo: Proteção dos Direitos Tradicionais Associados à Biodiversidade. Revista Jurídica. Disponível em: http://www.planalto.gov.br/ccivil_03/revista/rev_81/artigos/Simone_rev81.htm, retirado no dia 24.04.2015. 
Diante destes benefícios, inúmeras razóes podem ser arguidas para sua proteção. Dentre as quais, a primeira advém do fato de que a sua perda, gera também a perda de nossas identidades, culturas e tradiçôes, além da expropriação de recursos naturais. Não foi a toa que a Constituição Federal Brasileira determinou sua proteção à luz do que dispóem os artigos 215 e 216, além do inciso II, do artigo 225 deste diploma legal.

Cumpre ressaltar, que esse risco não é de forma alguma remoto. Para tanto, basta verificarmos alguns casos concretos em que a indústria farmacêutica vem espoliando os conhecimentos tradicionais, a saber:

O primeiro dos casos, diz respeito ao conhecimento tradicional indígena da toxina dos sapos. Habitualmente utilizado pelos índios para fins medicinais e também em suas flechas para fins de caça, o veneno de algumas espécies de sapos ${ }^{78}$ possui efeito analgésico e vem sendo estudado para fins de exploração por laboratórios farmacêuticos.

Um exemplo disso foi o caso da rã Epipedobates tricolor. Cujo veneno tradicionalmente utilizado como analgésico pelos povos indígenas da Amazônia, foi patenteado pelo laboratório norte-americano Abbot. Para isso, foi feita a retirada ilegal de 750 rãs desta espécie por seus cientistas. $\mathrm{O}$ que ocorreu sem qualquer permissão necessária, concedida por qualquer um dos países que a floresta Amazônica permeia.

Além deste caso, tivemos ainda a espoliação de outros vegetais como foi o caso urucum, da andiroba, etc., cuja utilização também advém de conhecimentos tradicionais de nossos índios.

Diante dos casos acima narrados, no ano de 2001, o Brasil editou a Medida Provisória no 2186. Seu objetivo era de regular o inciso II, do $\$ 1^{\circ}$ e o $\$ 4^{\circ}$, do artigo 225 da Constituição Federal. Essa medida foi recentemente revogada pela Lei no 13123, de 20 de maio de 2015.

No entanto, podemos dizer, que ambas as regulaçóes têm por objeto o acesso ao conhecimento tradicional associado à repartição de benefícios e ao acesso à tecnologia. Bem como, vislumbram também a sua transferência para conservação e utilização.

Mas, apesar disso, algumas questóes devem ser ressaltadas no que tange a esta nova lei. A primeira delas corresponde ao fato de que assim como sua antecessora, a Medida Provisória no 2186/2001, a Lei no $13123 / 2015$ busca regulamentar o artigo 225, \$\$ $1^{\circ}$ e $4^{\circ}$, da Constituição Federal. Além disso, buscou estar em consonância ao Decreto no 2519/1998 que conforme dito anteriormente internalizou a Convenção sobre a Diversidade Biológica.

7 Bichos do Brasil. Disponível em: http://www.bichosbrasil.com.br/sapogarimpeiro/, retirado em 25.05.2015.

8 Sapo Garimpeiro. Disponível em: http://www.upiranga.com/zoologico/sapo_garimpeiro.htm, retirado em 25.05.2015. 
Outra questão de grande relevância a ser destacada na nova lei foi a manutenção da competência exclusiva da Uniáo para gerir, controlar e fiscalizar as atividades de acesso ao patrimônio genético e ao conhecimento tradicional associado, nos termos do artigo $3^{\circ} \mathrm{e}$ seu $\$ único. E para tanto, a lei determina a necessidade de realização de cadastro, autorização ou notificação, além da fiscalização da atividade de acesso.

O artigo $6^{\circ}$ mantém o Conselho de Gestão do Patrimônio Genético (CGen) outrora previsto na Medida Provisória no 2186/2001. Trata-se de órgão colegiado e subordinado ao Ministério do Meio Ambiente. $\mathrm{O}$ que nos parece inadequado, já que a preocupaçáo com a proteção não deveria apenas se limitar ao patrimônio genético como também ao conhecimento tradicional individualmente.

Assim, pode acontecer de a existência de um conhecimento tradicional náo estar atrelada ao patrimônio genético. Como consequência ele estará à margem do alcance e controle do Conselho de Gestão do Patrimônio Genético. Esta interpretaçáo do artigo $6^{\circ}$ nos parece ratificada ante ao que dispóe o artigo $8^{\circ}$, caput, da Lei $n^{\circ} 13123 / 2015$, que passamos a transcrever:

Art. 8o Ficam protegidos por esta Lei os conhecimentos tradicionais associados ao patrimônio genético de populaçóes indígenas, de comunidade tradicional ou de agricultor tradicional contra a utilização e exploração ilícita. (grifo nosso)

Além disso, os parágrafos do supracitado artigo preveem também que o patrimônio cultural brasileiro "poderá ser" depositado em um banco de dados, apenas dependendo de disposição legal específica ou de sua criação pelo Conselho de Gestão do Patrimônio Genético. O que faz com que esta lei já nasça com sua efetividade um tanto quanto prejudicada.

No entanto, o pior ainda estaria por vir disposto no $\$ 3^{\circ}$ do mesmo artigo ora em comento. Isso porque, este dispositivo legal permite o livre acesso ao patrimônio genético de variedade tradicional local ou crioula ou à raça localmente adaptada, compreendendo inclusive o acesso ao conhecimento tradicional associado não identificável que deu origem à variedade ou a raça. Ora, tal disposição vai de encontro e colide diretamente com aquilo que se pretende proteger.

Ao que parece o legislador pátrio esqueceu-se do objetivo precípuo para criação da Lei no $13123 / 2015$, que era a proteção não só do patrimônio genético como também do conhecimento tradicional de seu povo. A afirmação torna-se nítida no momento em que a lei estabelece a competência e o dever de controle e fiscalização. Mas, sem, contudo, prever uma forma para sua publicização e oposição erga omnes. 
Inclusive, conforme informam Ferreira e Clementino ${ }^{9}$ foi nesse sentido que os membros da Organização Mundial da Propriedade Intelectual afirmaram que o Brasil não possui um sistema sui generis de proteção dos conhecimentos tradicionais. Além disso, eles elencaram algumas questóes que a Medida Provisória no 2186/2001 não elucidava ou quando fazia lhe faltava clareza e que em sua grande maioria ainda persistem em aberto na atual Lei em vigor. São elas ${ }^{10}$ :

- Proteção contra a apropriação indevida: Quais são os direitos?

- Alcance da matéria protegida: Que matéria deve ser protegida?

- Critérios em que se baseia a proteção: Que critérios deve reunir a matéria como condição de proteção?

- Duração da proteção: Quando se perdem ou como caducam os direitos?

- Consentimento prévio fundamentado: Como se aplica o princípio do consentimento prévio fundamentado?

- Repartição justa e equitativa dos benefícios: Como devem ser distribuídos os benefícios?

- Beneficiários da proteção: Quem deve se beneficiar da proteção?

- Aquisição dos direitos e formalidades: Como se adquirem os direitos?

- Administração e observância: Como se administram os direitos e como se vela pelo seu cumprimento?

Outra questão importante e digna de ponderação foi a de que a redação do artigo $2^{\circ}$ da Lei no 13123/2015 substituiu o termo "comunidade local" para comunidade tradicional e a definiu da seguinte forma:

VI- Comunidade Tradicional - grupo culturalmente diferenciado que se reconhece como tal, possui forma própria de organização social e ocupa e usa territórios e recursos naturais como condição para a sua reprodução cultural, social, religiosa, ancestral e econômica, utilizando conhecimentos, inovaçôes e práticas geradas e transmitidas pela tradição;

Tal fato acabou com a dubiedade que existia na Medida Provisória no 2186/2001 e trouxe em seu bojo o que "de fato" seria, pura e simplesmente, o conhecimento tradicional. E que neste diapasão, corresponderia aos "conhecimentos, inovaçóes e práticas geradas e

9 FERREIRA, SIMONE NUNES. CLEMENTINO, ADRIANA NOGUEIRA ROCHA. Artigo: Proteção dos Direitos Tradicionais Associados à Biodiversidade. Revista Jurídica. Disponível em: http:// www.planalto.gov.br/ccivil_03/revista/rev_81/artigos/Simone_rev81.htm, retirado no dia 24.04.2015.

10 Idem citação anterior. 
transmitidas pela tradição". Mas, que o legislador pátrio entendeu por bem ignorar e não proteger caso náo esteja atrelado ao patrimônio genético.

Ainda neste aspecto, não podemos esquecer que tanto na Medida Provisória ora revogada quanto na Lei no $13.123 / 2015$, existe a previsão de que a concessão de um direito de propriedade industrial pelos órgãos competentes, sobre processo ou produto obtido a partir de amostra de componente do patrimônio genético somente poderá ocorrer caso o requerente informe a origem do material genético e do conhecimento tradicional. Além disso, a lei atual vai ainda mais além ao exigir a apresentação de um termo de autorização do detentor deste conhecimento tradicional associado.

No entanto, entendemos que na prática esta exigência é um tanto quanto falha, tendo em vista que sequer possuímos catalogados os conhecimentos tradicionais e o patrimônio genético. Portanto, como opô-los a terceiros? E mais, como tornar esta oposição erga omnes internacionalmente? Enquanto a Lei Pátria não responder a este tipo de questionamento permanecerá falha e carente de efetividade. E desta forma, permanecemos com o risco de registro de novas patentes, feitas no exterior e cujo objeto seja um conhecimento tradicional brasileiro, agregado ou não a material genético de origem e possivelmente exclusividade nacional.

Para Sandra Akemi Shimada Kishi ${ }^{11}$ :

Os conhecimentos dessas populaçóes tradicionais são reconhecidos pela Constituição Federal de 1988 como patrimônio cultural brasileiro, bens de natureza imaterial ou material, tomados individualmente ou em conjunto. Integram a categoria de bens de interesse público, porque o artigo 129, V da CF/88 atribui ao Ministério Público a defesa judicial dos direitos e interesses das populaçóes indígenas, e coletivo lato sensu ou difuso, porquanto o elenco do inciso III desse comando do artigo 129 não é exaustivo, é exemplificativo. Por isso, ainda que apenas um indivíduo da comunidade tradicional detenha o conhecimento associado à biodiversidade, este sempre detém natureza coletiva.

A supracitada autora criticava que a natureza coletiva do conhecimento tradicional não era clara na Medida Provisória ora revogada pela Lei no $13123 / 2015$. Problema que foi surpreendentemente sanado por esta última lei.

Assim como na Medida Provisória a Lei no 13123/2015 prevê a fiscalização, interceptação e a apreensão de amostra de componente do patrimônio genético ou de produto obtido a partir de informação sobre conhecimento tradicional associado, bem como a previsão de recebimento pela União da parcela dos lucros e dos royalties frutos da

11 KISHI, Sandra Akemi Shimada. Conhecimento Tradicional. Disponível em: http//escola.mpu.mp.br/ dicionario/tiki-print.php?page=Conhecimento\%20tradicional, retirado em 14.04.2015. 
exploração econômica destes conhecimentos ou do patrimônio genético. No entanto, não temos um órgão responsável pelo registro e acervo dos conhecimentos tradicionais o do patrimônio genético brasileiro. A lei apenas se atém em dizer que o Conselho de Gestão do Patrimônio Genético poderia criar um banco para tal fim.

Além disso, em consonância com a Lei no 13123/2015 o decreto de no 5459/2005 estabelece que o procedimento de fiscalização acima citado será feito pelo Instituto Brasileiro do Meio Ambiente e dos Recursos Naturais Renováveis - IBAMA- e pelo Comando da Marinha, do Ministério da Defesa. O que, a nosso ver, gera óbice à sua proteção no âmbito internacional principalmente porque o porte e remessa do conhecimento tradicional e do patrimônio genético para o exterior podem ocorrer pelas vias aéreas e terrestre. Logo, dispor que a competência seja apenas destes dois órgãos nos parece temerário, ainda que passível de delegação.

Pois, muito embora tenhamos no âmbito internacional a previsão para sua proteção através da Convenção da Biodiversidade ${ }^{12}$, ela deixa ao crivo dos governos nacionais o estabelecimento da regulação para sua proteção, nos termos do artigo 15, 1, deste Acordo.

Neste sentido, perdemos a chance de blindarmos a proteção às nossas espécies nativas quando instituímos a Lei de Proteção aos cultivares (Lei de no 9456/97), tendo em vista que essa Lei teve por objeto tấo-somente a proteçáo a melhoria ou aperfeiçoamento de material genético vegetal, mas deixou sem proteção o próprio material em si.

Assim, apesar de sua importância para toda uma nação os conhecimentos tradicionais brasileiros estão hoje sob regulação cuja a proteção é exígua. Portanto, temos a necessidade de criação de novos meios para sua proteção.

Conforme dito antes, existem inúmeras razóes para a proteção dos conhecimentos tradicionais. A primeira razão, como vimos, é a de que sua perda vai também acarretar na perda de nossa identidade, de nossa cultura. Ao passo que, a segunda razão para proteção dos conhecimentos tradicionais vai decorrer do risco iminente de perda da diversidade cultural pela imposição de padróes culturais homogêneos. O que geraria como consequência à ausência de identidade cultural de um povo, ou ao menos o seu prejuízo.

Já a terceira razão para sua proteção decorre da violação paulatina que este instituto vem sofrendo através do aproveitamento individual de pessoas ambiciosas ou com interesses lucrativos. O que é demasiadamente comum e até mesmo impulsionado em uma sociedade em rede, tal como vivemos agora. A globalização não apenas transpôs fronteiras como também tornou possível o conhecimento de outras culturas à uma incomensurável distância. Fato que também torna propicia a espoliação deste tipo de conhecimento.

12 E que nada mais é que um tratado da Organização das Naçôes Unidas (ONU). 
Neste último aspecto, Caterine Castro ${ }^{13}$ vai defender que:

As tentativas de proteção jurídica dos conhecimentos tradicionais dos Povos Indígenas, no cenário internacional, não decorrem das próprias necessidades fundamentais desses sujeitos coletivos sob a premissa de que no âmbito dos fóruns internacionais multilaterais as tentativas de proteção foram formatadas pelo desejo ocidental de enquadrar os sistemas sociais e culturais dos povos indígenas no direito de propriedade intelectual e dos benefícios financeiros daí advindos.

E o efeito prático disso, é que não temos os conhecimentos tradicionais erigidos por sua importância sociocultural e sim, pelos benefícios financeiros que eles podem acarretar. E o pior, é que apesar disso conforme vimos a sua proteção é exígua na legislação pátria, principalmente no que tange a impossibilitar o seu patenteamento no exterior.

Assim, conforme defendido por Pierina German Castelli e John Wilkinson ${ }^{14}$ :

A produção do conhecimento nas comunidades indígenas não pode mais ser vista segundo o eixo "tradicional-moderno", mas deve ser entendida como um tipo de atividade de inovaçáo coletiva que envolve um alto grau de conhecimento não-codificável, uma característica que a literatura de inovação mostra poder igualmente estar presente nas atividades de alta tecnologia, como no caso de Silicon Valley.

Trata-se de uma mistura especifica de processos codificáveis/não-codificáveis e coletivos/individuais que exigem a elaboração equitativamente de todos os atores envolvidos no processo e que deve ser reconhecida no plano internacional em equivalência com outros regimes, sejam eles patentes, direitos autorais ou proteção de informaçáo confidencial.

No entanto, não acreditamos em tal equivalência defendida pelos supracitados autores. Pois, conforme eles escrevem ${ }^{15}$ :

Embora vários países em desenvolvimento tenham solicitado à Organização Mundial do Comércio (OMC) para que ela comissione estudos com vistas a identificar mecanismos de propriedade intelectual que promovam a proteçáo do conhecimento tradicional em nível global. Um dos maiores riscos nas negociaçóes ora em curso entre os países desenvolvidos e em desenvolvimento na questão da exploração da biodiversidade é o de que não sejam respeitadas as comunidades tradicionais.

13 CASTRO. Caterine Vasconcelos de. A Proteção do Conhecimento Tradicional dos Povos Indígenas sob a Concepção do Pluralismo Jurídico (dissertação). Universidade Federal de Santa Catarina, 2007.

14 CASTELLI, Pierina German. WILKINSON, John. Conhecimento Tradicional, inovaçáo e direitos de proteçáo. (UFRRJ). Disponível em: http://r1.ufrrj.br/esa/V2/ojs/index.php/esa/article/view/221, retirado em: 09.04.2015.

15 Idem 10. P 92. 
Desta forma, acreditamos sim, que a solução legal para sua proteção advém da conjugação com um instituto de propriedade industrial por nosso país já regulado e por todos os demais amplamente respeitados. Tratam-se das indicaçóes geográficas. Instituto esse, que preconiza a identificaçáo de um bem, produto ou serviço, em virtude de seu local de origem.

Em artigo recentemente publicado foi explicado que:

por indicaçóes geográficas denominam-se o instituto da Propriedade Industrial que protege e valoriza bem ou serviço de determinado país, local ou região, tornando-o ímpar em relação aos demais e agregando-lhe maior valor econômico ${ }^{16}$.

Esta individualização proporcionada pelas indicaçóes geográficas pode ocorrer sob duas óticas distintas. $\mathrm{Na}$ primeira delas, as características do país ou lugar influenciam diretamente sob o bem ou serviço. Ao passo que na segunda, o país ou lugar tem apenas por função a de identifica-lo. Entretanto, tanto em uma como na outra o fator humano não pode jamais ser ignorado, em virtude de ser o efetivo responsável pela extração ou produção do bem ou ainda, pela prestação do serviço que será único e distinguível em relação aos demais de mesmo gênero.

Assim, as indicaçóes geográficas podem ser classificadas como denominação de origem e indicação de procedência, dependendo de uma das óticas acima e sob a qual se adeque o bem ou serviço ao lugar com o qual deverá ser identificado.

No Brasil, a doutrina pouco se atém ao estudo deste instituto. Basicamente, os livros e manuais resumem-se a transcrever as definiçôes que lhes são dadas pela Lei no 9279/96. Desta forma, nos termos do artigo 177, da Lei no 9279/96, por indicação de procedência é considerado "o nome geográfico de pais, cidade regiâo ou localidade de seu território, que se tenha tornado conhecido como centro de extração, produção ou fabricação de determinado produto ou de prestação de determinado serviço". E nos termos do artigo seguinte, por denominação de origem é considerado "o nome geográfico de país, cidade, região ou localidade de seu território, que designe produto ou serviço cujas qualidades ou características se devam exclusiva e essencialmente ao meio geográfico, incluidos fatores naturais e humanos".

Conforme podemos perceber, a distinção tênue entre uma e outra classificação da indicação geográfica é a interferência do meio geográfico como um dos fatores determinantes da qualidade ou característica do bem ou serviço a ser designado.

16 LAGASSI, Veronica. Ensaios de uma Tese: A Certificação Geográfica para o Cultivo de Alimento Orgânico. (XXIII CONPEDI) Disponível em: www.publicadireito.com.br/publicacao/ufpb/livro. php?gt=210 
Desta forma, entendemos ser viável e possível o estabelecimento de correlação entre um dado patrimônio genético com o seu local de origem e assim, possibilitar a sua proteção por intermédio das indicaçóes geográficas. Neste caso, mais precisamente pelas denominações de origem.

Isso porque, o patrimônio genético corresponde a um bem nativo daquele local. Logo, sua existência e surgimento atribuem-se as qualidades da regiáo. Ao passo que, os conhecimentos tradicionais devem ser protegidos pelo instituto das indicaçóes de procedência pelo fato de não dependerem necessariamente das qualidades do local, mas sim dos conhecimentos de sua população. O que torna viável e juridicamente possível a proteção desses dois institutos através das indicaçóes geográficas e, além disso, facilitaria o trabalho de apreciação do Instituto Nacional da Propriedade Industrial (INPI) no pedido de concessão de novas patentes ante a possibilidade de detectação mais célere de patentes que fizessem uso destes institutos indevidamente.

Assim, ao reconhecer-se qualquer um destes dois institutos sob o qual se subdivide as indicações geográficas, como meio de proteção ao patrimônio genético e aos conhecimentos tradicionais. Estaríamos, sem dúvida alguma, evitando novas situaçóes de espoliaçóes ao patrimônio nacional. Tal como, lamentavelmente, ocorreu nos casos do vegetal andiroba, do urucum, da rã tricolor e tantos outros casos de apropriação pelos países estrangeiros de patrimônio genético e conhecimento tradicional. Pelo fato de a indicação geográfica tratar-se de um instituto da Propriedade Intelectual internacionalmente reconhecido e respeitado, em virtude do Agreement on Trade-Related Aspects of Intellectual Property Rights $(\text { TRIPS })^{17}$.

E caso fosse adotado este caminho, o Instituto Nacional da Propriedade Industrial (INPI) já seria o próprio agente catalogador e cadastrador dos conhecimentos tradicionais e do patrimônio genético, sendo desnecessária a criação do Conselho de Gestão do Patrimônio Genético e propiciando a simplificação do próprio INPI quando da análise de uma patente que envolva o patrimônio genético ou ainda, o conhecimento tradicional a ele associado. Muito embora, tal desburocratização seja apenas um dos pontos a serem questionados conforme demonstrado ao longo deste trabalho.

\section{Conclusões}

Em uma comunidade mundial aonde o conhecimento cultural, de idioma e local, entre tantos outros, perpassam por um click no mouse do computador, tablet ou celular. $\mathrm{O}$ que pode ser feito por qualquer pessoa e em qualquer lugar. Tornou-se necessária a

17 Trata-se de Acordo sobre Aspectos dos Direitos de Propriedade Intelectual Relacionados ao Comércio. 
criação e imposição de novas formas barreira, tidas como fronteira delimitadora da soberania nacional. E cujo fim precípuo seria tão-somente a manutenção da identidade e patrimônio cultural de um povo.

Conforme vimos, o Brasil lamentavelmente apenas preocupou-se com seu patrimônio genético. Pois, o conhecimento tradicional para ter proteção legal com base nas leis nacionais deve estar associado ao patrimônio genético. $\mathrm{O}$ que torna a lei inadequada, já que nada a existência de um tradicional que esteja dissociado do patrimônio genético nacional. E apesar disso, a lei no 13123/2015 assim como a sua antecessora não previu qualquer tipo de proteção por menor que fosse.

Além do ponto abordado, inúmeros foram os equívocos e lacunas legais existentes na legislação pátria e abordados neste trabalho. Possivelmente, o mais incisivo é sem dúvida alguma a delimitação clara do que por meio da Lei no 13123/2015 se quer proteger.

Não foi à toa que a OMPI já havia demonstrado inúmeros questionamentos a esse respeito, mas que foram ignorados ao analisar-se o texto da lei. Permanecemos sem proteção para o conhecimento tradicional. E, apesar de termos proteção para o caso de sua associação ao patrimônio genético, na prática, a mesma demonstra-se falha. Ante a impossibilidade brasileira de definição do que são considerados conhecimentos tradicionais brasileiros.

Assim, urge a necessidade do estabelecimento viável de algum meio de proteção que defendemos ser possível por intermédio das indicaçóes geográficas. Instituto pertencente ao campo da propriedade industrial que parece ser o mais adequado no que tange a proteção destes dois bens e patrimônios nacionais, das tentativas de espoliaçóes feitas pelos demais países.

Isso porque, conforme vimos, apesar de erigidos a preceitos de cunho constitucional os conhecimentos tradicionais e o patrimônio genético nacional carecem de proteção legal. Muito embora, possuam a Convenção da Diversidade Biológica da ONU e a Lei no $13123 / 2015$, cujo fim seria o de sua regulação e proteção. Mas que, conforme demonstramos são ineficazes na obtenção desse fim a que se destinam.

Desta forma, o conhecimento tradicional acompanhado ou não do patrimônio genético é propriedade ainda que imaterial de uma localidade e consequentemente, pertencente a um país.

Como propriedade esse tipo de conhecimento pode ser turbado e até mesmo espoliado, tal como foi o caso da andiroba, do veneno da rã tricolor, entre outros conhecimentos tradicionais que talvez nem tenhamos ciência de sua espoliação ante ao vasto território que representa a floresta Amazônica.

Com base nisso, não nos basta uma previsão constitucional efetivada por uma Lei Nacional que apenas preveja a fiscalização e a possibilidade de autorização para exploração 
do conhecimento tradicional associado ao patrimônio genético. Se, na prática, esse sistema tem tudo para não funcionar. A começar pela previsão de pagamento de royalties e de participação nos lucros para sua exploração. Pois, se não há previsão efetiva e respeito desses dois institutos por partes dos países estrangeiros, em especial os desenvolvidos, também possivelmente não haverá respeito para esse tipo de acordo. Vez que seu descumprimento não inviabilizaria o registro em órgão similar ao INPI feito em outro país.

Ademais, ainda que se faça essa parceria entre o país proprietário e um terceiro a Lei não é clara no que tange ao repasse dos royalties para o local ou região de origem do conhecimento tradicional associado. E tampouco, ela estabeleceu parâmetros para elaboração do acordo de cooperação entre eventuais países envolvidos. Isso sem cogitar a hipótese de um mesmo conhecimento tradicional poder pertencer a diversos países.

Indubitavelmente, nosso papel aqui na conclusão foi de apenas deixar no ar as inúmeras questóes que envolvem o tema.

\section{Referências}

BRASIL. Medida Provisória no 2186/2001. Disponível em: https://www.planalto.gov. br/ccivil_03/MPV/2186-16.htm, retirado em: 15.11.2014.

. Constituiçáo Federal da República Federativa do Brasil de 1988. Disponível em: http://www.planalto.gov.br/ccivil_03/Constituicao/Constituicao.htm, retirado em: 15.11.2014.

. Lei no 9279/96 (Lei de Propriedade Industrial). Disponível em: http://www. planalto.gov.br/ccivil_03/Leis/L9279.htm, retirado em: 05.04.2015.

. Lei no 9456/97 (Lei de Proteção de Cultivares). Disponível em: http://www. planalto.gov.br/ccivil_03/Leis/L9456.htm, retirado em: 22.04.2015.

. Lei no 13123/2015 (Lei dos Conhecimentos Tradicionais). Disponível em: http:/www.planalto.gov.br/CCIVIL_03/_Ato2015-2018/2015/Lei/L13123.htm, retirado em 22.05.2015.

. Decreto no 2519/98. Disponível em: http://www.planalto.gov.br/CCIVIL_03/ decreto/D2519.htm\#anexo, retirado no dia 27.05.2015.

BRUSH, Stephen B. Whose Knowledge, Whose Genes, Whose Rights? In: Valuing Local Knowledge: Indigenous People and Intellectual Property Rights. Edited by Stephen B. Brush e Doreen Stabinsky, 1996.

CASTELLI, Pierina German. WILKINSON, John. Conhecimento Tradicional, inovaçáo e direitos de proteçáo. (UFRRJ). Disponível em: http://r1.ufrrj.br/esa/V2/ojs/ index.php/esa/article/view/221, retirado em: 09.04.2015. 
CASTRO. Caterine Vasconcelos de. A Proteçáo do Conhecimento Tradicional dos Povos Indígenas sob a Concepçáo do Pluralismo Jurídico (dissertação). Universidade Federal de Santa Catarina, 2007.

FERREIRA, SIMONE NUNES. CLEMENTINO, ADRIANA NOGUEIRA ROCHA. Artigo: Proteção dos Direitos Tradicionais Associados à Biodiversidade. Revista Jurídica. Disponível em: http://www.planalto.gov.br/ccivil_03/revista/rev_81/artigos/Simone_rev81.htm, retirado no dia 24.04.2015.

HALL, Stuart. (Tradução de Tomaz Tadeu da Silva e Guacira Lopes Louro). A Identidade Cultural na Pós-modernidade. 11 a edição. Rio de Janeiro: DP\&A Editora, 2011.

KISHI, Sandra Akemi Shimada. Conhecimento Tradicional. Disponível em: http// escola.mpu.mp.br/dicionario/tiki-print.php?page=Conhecimento $\% 20$ tradicional, retirado em 14.04.2015.

LAGASSI, Veronica. Ensaios de uma Tese: A Certificação Geográfica para o Cultivo de Alimento Orgânico. (XXIII CONPEDI) Disponível em: www.publicadireito. com.br/publicacao/ufpb/livro.php?gt=210.

MELO, Ezi. Estrangeiros registram patentes sobre produtos da Amazônia. Fonte: A Gazeta, Rio Branco - AC - 27/12/2002. Disponível em: http://www.abfit.org.br/ noticias/outros-anos/antes-de-2012/21-estrangeiros-registram-patentes-sobre-produtos-da-amaz\%C3\%B4nia, retirado em 19.04.2015.

MINISTÉRIO DO MEIO AMBIENTE. Convenção da Biodiversidade. Disponível em: http://www.mma.gov.br/biodiversidade/convencao-da-diversidade-biologica, retirado em 22.04.2015.

Sapo Garimpeiro. Disponível em: http:/www.upiranga.com/zoologico/sapo_garimpeiro.htm, retirado em 25.05.2015.

Bichos do Brasil. Disponível em: http://www.bichosbrasil.com.br/sapogarimpeiro/, retirado em 25.05.2015. 